NBER WORKING PAPER SERIES

ON

HISTORICAL FACTORS IN LONG RUN GROWTH

\title{
CHILDHOOD MORTALITY \& NUTRITIONAL STATUS AS INDICATORS OF STANDARD OF LIVING: EVIDENCE FROM WORLD WAR I RECRUITS IN THE UNITED STATES
}

\author{
Michael R. Haines \\ Richard H. Steckel \\ Historical Paper 121 \\ NATIONAL BUREAU OF ECONOMIC RESEARCH \\ 1050 Massachusetts Avenue \\ Cambridge, MA 02138 \\ January 2000
}

Paper originally prepared for the session "Is There a Biological Standard of Living? The Relationship \& Interchangeability of Different Indicators for Measuring the Standard of Living" at the annual meetings of the Social Science History Association, Washington, DC, October 16-19, 1997. The paper will appear in a special issue of the Jahrbuch fuer Wirtschaftsgeschichte edited by John Komlos. Michael R. Haines is Banfi Vintners Professor of Economics, Colgate University and Research Associate, National Bureau of Economic Research, Cambridge, MA. Richard H. Steckel is Professor of Economics and Anthropology, The Ohio State University, and Research Associate, National Bureau of Economic Research. This project was funded, in part, by National Institute of Child Health and Human Development (1 RO1 HD-24106). Any opinions expressed are those of the authors and not those of the National Bureau of Economic Research.

(C) 2000 by Michael R. Haines and Richard H. Steckel. All rights reserved. Short sections of text, not to exceed two paragraphs, may be quoted without explicit permission provided that full credit, including $\mathbb{O}$ notice, is given to the source. 
Childhood Mortality \& Nutritional Status as Indicators of Standard of

Living: Evidence from World War I Recruits in the United States

Michael R. Haines and Richard H. Steckel

NBER Historical Paper No. 121

January 2000

JEL No. N3

Development of the American Economy

\section{ABSTRACT}

This paper examines variations in stature and the Body Mass Index (BMI) across space for the United States in $1917 / 18$, using published data on the measurement of approximately 890,000 recruits for the American Army for World War I. It also connects those anthropometric measurements with an index of childhood mortality estimated from the censuses of 1900 and 1910 . This index is taken to be an indicator of early childhood environment for these recruits. Aggregated data were published for states and groups of counties by the Surgeon General after the war. These data are related to regional data taken primarily from the censuses of 1900 and 1910. The results indicate that early childhood mortality was a good (negative) predictor of height and the body mass index, while it is also possible to predict early childhood experience from terminal adult height. Urbanization was important, although the importance declined over time. Income apparently had little effect on health in this period.

Michael R. Haines

Department of Economics

Colgate University

13 Oak Drive

Hamilton, NY 13346

and NBER

mhaines@center.colgate.edu
Richard H. Steckel

Department of Economics

The Ohio State University

1945 North High Street

Columbus, OH 43210-1172

and NBER

steckel.1@osu.edu 


\section{INTRODUCTION}

There is now a substantial literature indicating that outcomes are often preferable to inputs as indicators of human welfare and economic progress. For example, the United Nations has proposed the Human Development Index and the World Bank uses Basic Needs Indicators. ${ }^{1}$ In this view, outcomes such as expectation of life at birth, the infant mortality rate, literacy, years of schooling completed, and average calorie or protein consumption are complements, or alternatives, to traditional measures of inputs in the utility function such as GDP per capita. More recently, the concept of a biological standard of living has been introduced.2 This literature looks at such phenomena as terminal adult heights, height for weight, child and adolescent growth paths, and evidence of growth and disease from human remains. ${ }^{3}$

Interesting and important results have arisen from this research program. For instance, it seems that economic growth and development in the antebellum United States was a mixed blessing. Although product per capita was rising robustly over the two to three decades prior to 1860, native-born Americans were becoming shorter. ${ }^{4}$ Since data on mortality for this period are sparse, this provides an indication that mortality might actually have been worsening while the economy was growing. The negative externalities from urbanization, substantial immigration from Europe, and the increased circulation of people and commerce within the nation contributed to this pattern. This negative trend in the biological standard of living was apparently not reversed until the late $19^{\text {th }}$ century, around the time that many recruits for World War I were born. ${ }^{5}$

On yet another dimension, part of the increase in labor productivity accompanying modern economic growth is attributable to improvements in human capital, a portion of which, in turn, was due to improved health and reduced morbidity and mortality. While the measurement of health is not easy, some progress has been made. One approach is to use morbidity data from insurance and medical records to assess actual or potential working time lost to sickness. ${ }^{6}$ Another possibility is to utilize measures of human growth, such as terminal adult heights, child heights at various ages, and height by 
weight data, to assess outcomes in terms of physical development. Such information, both aggregated and in micro form, have now been extensively used to study health, nutrition, mortality, and labor productivity in a number of nations and regions from the seventeenth to the twentieth centuries.7 For the United States the most important findings are the achievement of relatively large adult stature among white males in the British North American colonies by the late eighteenth century (with terminal heights of 172-173 cm, or about 69 inches); a deterioration in terminal heights for native-born white males from about the 1830's to about 1910, when mean heights reached approximately $169 \mathrm{~cm}$ (about 66.5 inches); and a rise in stature after about 1910. (See Table 1.) These movements tended to follow swings in the expectation of life with about a 10 to 30 year $\operatorname{lag} \cdot{ }^{8}$

Data on human growth and development thus constitute an excellent source for the study of health and the state of human capital, as well as the standard of living. In particular, there is evidence that terminal heights are positively correlated with per capita income and negatively correlated with mortality levels. ${ }^{9}$ While the mechanisms and links are not fully clarified, there is ample theory to make these links and the statistical evidence is quite suggestive.

The principal sources for such studies have been military recruitment records. Such data have been collected and analyzed for the colonial American muster rolls; ${ }^{10}$ American Civil War records for the Union Army; ${ }^{11}$ Sweden in the eighteenth and nineteenth centuries; ${ }^{12}$ the Habsburg Monarchy in the eighteenth century; ${ }^{13}$ a variety of historical populations in the United States, ${ }^{14}$ France, ${ }^{15}$ Germany, ${ }^{16}$ the Netherlands; ${ }^{17}$ nineteenth and early twentieth century British military induction records; ${ }^{18}$ as well as Australia, Argentina, Japan, Spain, and Greece. ${ }^{19}$ The present paper provides additional information on the relationship between physical stature and health using data on inductees into the United States Army during World War I.

WORLD WAR I RECRUITMENT DATA FOR THE UNITED STATES 
In preparing a draftee army for entry into the Great War in 1917 and 1918, the U.S. Army Surgeon General's Office provided guidelines for physical measurement and examination of recruits. This was in the long-standing tradition of examining recruits for such information as general health; specific physical defects and diseases; literacy; and height, weight, and other bodily measurements to provide data for uniform and shoe sizes, ration requirements, and marching and weight-carrying capacities. Selected results of the American induction process were published by Davenport and Love for the Surgeon General.20 Heights and weights (and other measurements) were published for 892,467 of the first million recruits. They had a mean height of $171.4 \mathrm{~cm}$ or 67.49 inches. There appears to have been little bias due to minimum height truncation, although there was a minimum height requirement of 61 inches from June, 1917 to February, 1918, which was lowered to 60 inches thereafter. The average weight of the recruits was 141.54 pounds. ${ }^{2}$ These figures compare to heights of about 68.1 inches for colonial troops during the American Revolution, about 68 inches for Army volunteers during 1818, and 67.7 inches for native white troops during the American Civil War. ${ }^{21}$ From those data, it seems that American soldiers in World War I were recruited at older ages than their Civil War counterparts. The proportion of those under age 20 was $21.8 \%$ among Civil War volunteers but only 5.4\% in 1917/18.22 This obviates somewhat the problem that the terminal age for growth had not yet been reached among many of the World War I recruits.

There were some serious shortcomings in the original data collection, however. For example, race, nativity, age, and occupation were not recorded on the original forms. Subsequently 103,212 recruits were remeasured at demobilization in 1919, when such data were recorded. Most of the information used in this study was from measurement of the first one million recruits, but some has been taken from the sample at demobilization. Efforts were made to recruit blacks in proportion to their approximate representation in the national population in 1910 (11.4\% of the total population). Instructions were given to recruitment and draft authorities to enlist one black for 
each seven whites. Ultimately, about 404,000 blacks served in the army in World War I. Blacks thus constituted about $10 \%$ of the army. ${ }^{23}$ In the demobilization survey of 1919 , only 6.2\% were African-American. ${ }^{24}$ Although blacks were underrepresented in the demobilization sample, that sample did show that the heights of black soldiers were virtually identical to those of white soldiers (67.70 inches average for blacks verus 67.71 inches for whites). It is interesting that no difference appeared despite the disadvantaged status of the black population. ${ }^{25}$

We lack the micro data directly to disentangle the effects of variables such as race, nativity, and residence. There exists, however, aggregate evidence on heights and weights, published by state of origin and also for 156 clusters of counties of origin. The latter were intended to be somewhat more homogeneous along economic, climatic, topographic, and ethnic dimensions. ${ }^{26}$ To enhance analysis, these anthropometric data have been augmented by census and other information. These include measures of state income for $1900 ;^{27}$ a variety of demographic data from the 1900 and 1910 censuses; number of medical doctors in 1900; and an index of child mortality estimated by indirect techniques and based on nationally representative census samples for 1900 and 1910.28

The index of childhood mortality in this paper uses the information on children ever born, children surviving, and the duration of current marriage for adult women recorded in the censuses of 1900 and 1910. However, these questions were not tabulated at the time, and only some results on children ever born from the 1910 manuscripts were used in connection with the 1940 census. The underlying data are from the Integrated Public Use Microsamples (IPUMS) of the original manuscript of the 1900 and 1910 United States Censuses of Population. ${ }^{29}$ The 1900 sample comprises 100,438 individuals in 27,069 households of whom 13,429 adult women met the criteria for estimation (i.e., currently married, once married, married less than 25 years, responses on children ever born and children surviving known, and no obvious inconsistencies such as implied age at marriage less than 12 years of age and children surviving greater than children ever born). The 1910 sample contains 366,239 individuals in 88,814 households, of whom 42,075 adult 
women were the basis for the estimation of the child mortality index for states and for county groups.

The index is the ratio of actual to expected child deaths for individual women or groups of women. Actual child deaths are calculated as the difference between stated children ever born and stated children surviving. Expected child deaths are calculated by multiplying children ever born for each eligible women by the expected child mortality based on a national average of each marriage duration group (0-4, 5-9, 1014,..30-34). It is a way of comparing actual child mortality to that expected from the national average. The use of marriage duration categories to calculate the index is a means of standardizing for the length of exposure to risk of mortality for the children. The overall totals are close to the national average. That is, the ratio is close to unity for the country as a whole (.9874 for 1900 and .9800 for 1910). It is calculated only for once married, currently married women for whom children ever born, children surviving, and marriage duration were all known. The intuitive interpretation is that ratios above one showed greater than average mortality with ratios below one showing more favorable experience. The mortality index calculated from the 1900 census sample applies to a date on average of about 1894, while that calculated from the 1910 census sample has an average reference date of 1903/04. This would cover the childhood experience of most World War I veterans, 97\% of whom were below 35 years of age.

THE BIOLOGICAL STANDARD OF LIVING IN THE EARLY $20^{\text {TH }}$ CENTURY

The information in Table 1 confirms that heights close to modern levels had been achieved already by the time of the American Revolution. But by World War I, mean heights had still not recovered to the levels attained at the time of the Civil War, which were, in turn, still lower than those of a few decades earlier. The recovery in this index of the biological standard of living from the late $19^{\text {th }}$ century was impeded by rapid urbanization and the large influx of foreign born, both of which worsened mortality for a period. It was, on the other hand, assisted by the onset of the 
mortality transition, which commenced overall in the 1870 s and was in full swing by the early $20^{\text {th }}$ century. ${ }^{30}$

At the time of the First World War, as heights were increasing again, there was substantial variation in both heights and BMIs across states and smaller geographic units. (See Maps 1 and 2). The tallest recruits were found in Texas at 68.4 inches, while the shortest were from Rhode Island at 66.4 inches. By standards of anthropometry, these are quite substantial differences within a society. The more rural, agrarian character of Texas (24\% urban in 1910) and its low proportion of foreign-born (6.2\%) may be contrasted to the heavily urban (91\%), industrial, and foreign-born (33\%) population of Rhode Island. There was also a good deal of geographic clustering. The shortest recruits were concentrated in the Northeast, while the tallest were found in parts of the South and West North Central Region (Map 1). In contrast, the most robust young men were, in terms of BMI, found in the Dakotas (with BMIs of about 22.4), while the leanest ones were from the upper South in Kentucky and Tennessee (with BMIs of about 21.3). These BMI values were relatively low by modern standards. For example, Americans in 1959-62 in their 20s had a mean BMI of 24.5. ${ }^{31}$ Again, there was considerable geographic concentration, with the most robust recruits coming from the West and upper Midwest and the leanest originating in the South.

Several questions can be investigated with these data. Did differences across space in the terminal heights or in height for weight (as measured by the BMI) for 1917-18 predict differences for the same geographic units in infant and child mortality 15 to 25 years before? Holding several other variables constant, how much of the variation in terminal heights (or height for weight) across states and county groups can be explained by income differences, by urban conditions, and by ethnic composition? Or, reversing the original question, did childhood health conditions for this cohort of military recruits (proxied by the child mortality index of 10-25 years prior) predict the terminal heights or the height for weight achieved as young adults? Table 2 provides an analysis of the 48 states of the contiguous United States plus 
the District of Columbia. ${ }^{2}$ Table 3 does the same for the county groups for which mean heights and weights were reported by Davenport and Love. ${ }^{33}$ Both tables present means, standard deviations, zero-order correlations, and ordinary least squares regressions with the child mortality index, mean heights, and mean BMI being in turn the dependent variables. The independent variables include the proportions of each geographic unit urban (in incorporated areas of 2,500 or more), black, foreign born, and illiterate (among the population aged 10 and over); medical doctors per 10,000 population (for 1900 for states); persons per dwelling and family; earnings per worker and income per capita (both for 1900); dummy variables for region of residence; the mortality index; and average heights, weights, and BMIs. ${ }^{34}$

An underlying assumption is that the place of recruitment is a good proxy for conditions experienced in childhood. That is clearly not true for everyone, especially the foreign-born recruits who were likely to have migrated at older ages. American society was also notable for its geographic mobility. ${ }^{35}$ Nonetheless, most of the recruits were native born and were young men who had probably not gone far from their area of origin. ${ }^{36}$

What of the results? First, it appears that much of the variation (between $28 \%$ and 82\%) in child mortality, stature, and BMI across states and county groups can be explained by the right hand side variables in the models. The independent variables were generally much more successful in accounting for variation in stature and BMI than for variation in the child mortality index. Adjusted $R^{2}$ values ranged from .66 to .81 in Tables 2 and 3 for the anthropometric models, but were much less for the mortality models. The relationship of childhood mortality to the anthropometric measures for both the correlations and the regressions was in the expected direction and often statistically significant. That is, the higher was the mortality in prior decades in the recruitment area, the shorter were the recruits, who also had lower BMIs. Similarly, areas where those recruits with lower indices of the biological standard of living resided had higher childhood mortality at an earlier point in time. This 
suggests that anthropometric measures might constitute reasonable predictors of prior mortality conditions, useful when mortality data are lacking.

It is somewhat puzzling that the regressions performed poorly for the child mortality index. ${ }^{37}$ The results suggest that heights and the mortality index measure somewhat different aspects of health. Many people who are malnourished and subjected to a harsher childhood disease environment may survive, but at a shorter stature. Mortality is thus an extreme manifestation of poor health, whereas average height (and BMI) capture some deprivation that does not end up in death. Alternatively, in this era some numbers of deaths occurred from diseases that were not very nutrition sensitive. Although the interaction between nutrition and specific diseases is complex and not always well understood, some diseases have been identified as nutritionally sensitive. ${ }^{38}$ If we take such diseases and relate them to the causes of death reported for persons aged 0-14 in the American Death Registration Area of 1900, we find that 48\% of the causes could be classified as nutritionally sensitive, 15\% as ambiguously or variably sensitive, and 37\% as not sensitive. ${ }^{39}$ Thus, a third to a half of deaths at young ages were related to causes not sensitive to early childhood nutrition - a major determinant of adult height.

Urbanization had a negative effect on the biological standard of living, even during this period of rapid mortality transition when the urban mortality penalty was being eliminated. The regression coefficients had the expected signs: positive in the mortality models for 1900 and negative in the stature and BMI equations. Interestingly, the simple correlations had the opposite signs, indicating the value of multivariate analysis here. In the mortality equations, the effect diminished over time, as seen by comparing the coefficients using the 1900 versus the 1910 census data. In the case of both the state and county group data, the urbanization coefficient remained positive (the expected sign) but diminished in size. It became statistically insignificant in the 1910 state mortality model. The proportion of the population black and foreign born (expected to be associated with poorer outcomes) did not show a consistent relationship 
to mortality, stature in the state models, once other variables had been controlled.

The simple zero-order correlations were more consistent.

The proportion black was omitted from the anthropometric models for reasons already noted -- there was no perceptible difference in heights between black and white recruits.40 In the mortality equations, a higher proportion black led to the unexpected result of lower child mortality in three of the four equations (state and county group, mortality index of 1900 and 1910). That may have been due to the healthier conditions in rural areas, which were not captured in the urban variable. (In 1900, approximately $80 \%$ of the black population was rural.) The proportions foreign born in the mortality equations were uniformly statistically insignificant, although negative in sign in three of four cases. This is also unexpected. The results for the proportions foreign born in the anthropometric models were a bit more consistent. The variable was strongly positively associated with BMI (rather surprising) and negatively correlated with stature in two of three instances. In the county group models, the proportion foreign born was statistically significant for both height and BMI, while the coefficients were significant in the state models only for BMI. The positive relationship of the proportion foreign born to BMI is especially puzzling, since this variable showed a strong negative association with height. A possible explanation is that poor disease and nutritional conditions in the overseas areas of birth and childhood permanently stunted these migrants, but that the recruits were able to gain a good deal of weight once they had the opportunity to consume the American diet, relatively abundant in calories and protein from dairy products and meat. Since BMI is more an indicator of later life health, this would seem plausible.

When the proportion of the population aged 10 and over who were illiterate was included as an explanatory variable in both the state and county group mortality models, it seemed to be a good proxy for disadvantaged status. This variable, however, suffered from problems of multicollinearity. Consequently, it was omitted from the 1900 state anthropometric models. The variables persons per dwelling and persons per family, taken 
as indices of crowding, did not perform well. Persons per dwelling was really a proxy for urbanization, and hence was dropped from all the models. Persons per family did not perform well in the anthropometric models and also suffered from collinearity problems. For childhood mortality, it actually predicted lower levels, the opposite of the one expected. Medical doctors per 10,000 population, a possible index of medical care, only showed a statistically significant (positive) regression relationship to heights for states. The income variable (earnings per worker) had the correct sign (negative for mortality and positive for heights and BMI for the state data in Table 2) but was never statistically significant.

Importantly, regional variation was influential independent of the other variables for the case of stature and the BMI, but not for mortality. Thus, many of the regional effects had not been captured by the explanatory variables in the models for the anthropometric indices. Both Tables 2 and 3 report the adjusted $\mathrm{R}^{2}$ values for a specification which only included the regional dummy variables. For states using the 1900 data, just knowing region alone could explain 69\% in the variation in height and $48 \%$ of the variation in BMI, compared with $81 \%$ and $72 \%$ respectively when the other variables were included. The results were similar for the 1910 state data. For the county groups, just knowing region of recruitment could account for $62 \%$ of variation in stature and $44 \%$ of variation in the BMI, in contrast to $79 \%$ and $66 \%$ respectively for the full models. This confirms the geographic concentration of height and BMI seen in Maps 1 and 2. Regional differences in stature in 1917/18 were rather considerable: about five centimeters or two inches across states and county groups. The regional dummy variables actually do a reasonably good job of accounting for height, though the magnitudes of the coefficients do not give such a large effect as two inches.

For mortality, in contrast, region alone explained only 13-18\% of variation across states, as opposed to 50-60\% when socioeconomic variables were added. For county groups, the contrast was 4-15\% for region alone and 28-51\% for all variables. Clearly, the mortality pattern was more geographically heterogeneous in this period. This was a 
likely consequence of the uneven pattern of the mortality transition, well underway by the first decade of the $20^{\text {th }}$ century. Map 3, which portrays the child mortality index by states for 1910, shows some limited clustering but considerable regional heterogeneity.

DISCUSSION

What then have we learned from this exercise? First, this paper has examined the relationship between anthropometric indicators of health and mortality, which helps to explain what an inch of height means to social scientists. This is an agenda which has been pursued for two decades in the anthropometric literature - comparing average heights with other social indicators such as per capita income and mortality rates. ${ }^{41}$ In the present instance, across states a one point (about 1\%) reduction in childhood mortality index around 1895 would have resulted in a .27 inch increase in stature. For childhood mortality centered around 1903/1904, the increase in height would have been about .55 inch. For the county group data and the 1910 mortality index, the height increase would have been around .29 inch. These are substantial effects. Second, measurement of regional differences in health in the United States has not been historically abundant. ${ }^{42}$ While we have regional income estimates after 1840,43 we do not have as them on health. Maps 1 and 2 show substantial regional clustering both height and BMI. The shortest recruits came from the Northeast and eastern Midwest and the tallest from the western South, part of the Mountain region, and the upper Midwest. In contrast, the least robust recruits (measured by BMI) originated in the South and the most robust in the Northeast, upper Midwest, and far West.

It appears that large health differentials did exist in the United States early in the 20th century, especially when using height as an indicator. Stature differences were relatively large by modern standards - a range of two inches between Texas and Rhode Island. The childhood mortality index also showed very large variation across states from .57 in Vermont to 1.9 in New Mexico in 1910, although rather different aspects of health experience were being measured. 
Socioeconomic factors do provide clues to the sources of these regional health differences. An analysis of variance explained is illustrative. For states in 1900, the adjusted $R^{2}$ value for the socioeconomic variables without regional dummy variables was .501 when predicting the mortality index. It was .039 when only regional dummies were the explanatory variables and .505 when all variables were included. The result for states in 1910 was quite similar. For county groups, the adjusted $R^{2}$ value was .471 in predicting the 1910 mortality index with only the socioeconomic variables included in the model, but it was .176 for regional dummies alone and .51 for all variables included. Clearly, the socioeconomic factors accounted for much more of the observed variation in childhood mortality than regions alone. The results for height were quite different. Socioeconomic variables alone explained .659 of the variation in heights for states in 1900, while the regional dummies accounted for .69. Both sets of variables together gave an adjusted $\mathrm{R}^{2}$ of .806 . For county groups the results were .49 for socioeconomic variables, .622 for regional dummy variables, and .793 for all variables. The analysis for BMI was similar to that for height. This suggests that regional clustering of anthropometric measures of health was significant in the early $20^{\text {th }}$ century, but that childhood mortality was more spatially diffuse. This is consistent with the contention that public health improvements could affect mortality much more quickly than nutrition and generalized standard of living, the latter being more likely to affect stature. ${ }^{44}$ Socioeconomic variables explain relatively well the spatial differences in all cases. Urbanization tended to be one of the main factors increasing mortality and leading to shorter stature. Adult illiteracy, an index of lack of socioeconomic advancement, had a strong effect in raising childhood mortality. Mortality itself 13-24 years prior to World War I predicted shorter heights and (for states) lower BMI. Also, recruit heights for states and county groups in 1917/18 was able significantly to predict childhood mortality in 1910 .

In general, then, even with substantial international and internal migration and other confounding factors, it appears that height and height for weight are reasonable 
social indicators and can assist in evaluating the state of health and the biological standard of living within the United States in the early twentieth century. This is a particularly important period, because the mortality transition was fully underway. Even during the critical period 1890-1920, however, urbanization continued to exhibit a strong effect on both childhood mortality and stature in the expected directions. In other words, the "urban penalty" had not yet been eliminated.

Mortality itself, particularly infant and childhood mortality, are excellent social indicators; but we lack complete mortality information on mortality conditions around 1900, since national coverage by vital registration (of births and deaths) was not complete until 1933. The census-based indirect estimates (the child mortality index) used here are good substitutes, but they are based on samples and must be extended to adult mortality. Anthropometric measures can supplement that information.

Substantial variation in both mortality and anthropometric outcomes was characteristic of the era. It seems that childhood health conditions can provide reasonable predictions of stature and height for weight in adulthood. More Importantly, there is a case to be made for using auxological data for backcasting mortality predictions, especially valuable for time periods and locations lacking good mortality data but having information on anthropometry. Most of the $19^{\text {th }}$ century has inadequate statistical information. The results in this paper confirm that the urban mortality penalty, which had only begun to diminish substantially by the late 19th century, was still influencing health conditions in the early $20^{\text {th }}$ century. The shortest recruits came from the most urbanized and industrialized states and counties in the northeastern United States. The most robust recruits came from the western upper Midwest and the West, while the leanest originated in the South. These are results undoubtedly related to the epidemiological, health, dietary, and general living conditions prevailing in those regions. 
TABLE 1. HEIGHTS OF NATIVE-BORN WHITE MALES. UNITED STATES, 1755-1944.

$\begin{array}{llcc}\begin{array}{l}\text { DATES OF } \\ \text { MEASUREMENT }\end{array} & \text { AGE } & \begin{array}{c}\text { SAMPLE } \\ \text { SIZE }\end{array} & \begin{array}{c}\text { MEAN } \\ (\mathrm{cm})\end{array} \\ 1755-63(\mathrm{a}) & 24-35 & 767 & 172.0 \\ 1755-63(\mathrm{~b}) & 21-30 & 885 & 172.2 \\ 1775-83 & 24-35 & 968 & 172.9 \\ 1861-65 & 25-30 & 123,472 & 173.2 \\ 1917-18 & 21-30 & 868,445 & 171.4 \\ 1943-44 & 20-24 & 119,443 & 173.2\end{array}$

SOURCE: Reproduced from R.H. Steckel, "Stature and Living Standards", Table 6.7. 17551763 (a) and 1775-1783: K.L. Sokoloff/G.C. Villaflor, The Early Achievement of Modern Stature in America, in: Social Science History, 1982 6, pp. 453-481. 1755-1763 (b): A.T. Steegmann, Jr./P.A. Haseley, Stature Variation in the British American Colonies: French and Indian War Records, 1755-1763, in: American Journal of Physical Anthropology, 1988 75, pp. 413-421. 1861-1865: B.A. Gould, Investigations in the Military and Anthropological Statistics of American Soldiers, Cambridge, MA 1869. 1917-1918: C.B. Davenport/A.G. Love, Statistics: Army Anthropology, Vol. 15, Part 1, Medical Department, U.S. Army, The Medical Department of the United States Army in the World War, Washington, DC 1921. 1943-1944: B.D. Karpinos, Height and Weight of Selective Service Registrants Processed for Military Service during World War II, in: Human Biology, 1958 30, pp. 292-321. 
1. United Nations, United Nations Human Development Program, Human Development Report, 1990, New York 1990. D. Morawetz, Twenty-five Years of Economic Development, Baltimore, MD 1977.

2. R.W. Fogel, Nutrition and the Decline in Mortality since 1700: Some Preliminary Findings, in: S.L. Engerman/R.E. Gallman, eds. Long-Term Factors in American Economic Growth, Chicago 1986, pp. 439-555. R.H. Steckel, Height and Per Capita Income, in: Historical Methods 16 1983, pp. 1-7. R.H. Steckel, Stature and Living Standards in the United States, in: R.E. Gallman/J.J. Wallis, eds., Economic Growth and Standards of Living before the Civil War, Chicago 1992, pp. 265-308. R.H. Steckel, Stature and the Standard of Living, Journal of Economic Literature 33 1995, pp. 1903-1940. J. Komlos, ed., Stature, Living Standards, and Economic Development: Essays in Anthropometric History, Chicago 1994. J. Komlos, The Biological Standard of Living in Europe and America, 1700-1900, Aldershot, Eng. 1995. J. Komlos, ed., The Biological Standard of Living on Three Continents: Further Explorations in Anthropometric History, Boulder, CO 1995. J. Komlos/J. Baten, eds., The Biological Standard of Living in Comparative Perspective, Stuttgart 1998.

3. For the United States, see Fogel, Nutrition and the Decline in Mortality since 1700. D.L. Costa/R.H. Steckel, Long-Term Trends in Health, Welfare, and Economic Growth in the United States, in: R.H Steckel/R. Floud, eds., Health and Welfare during Industrialization, Chicago 1997, pp. 47-89.

4. J. Komlos, The Height and Weight of West Point Cadets: Dietary Change in Antebellum America, Journal of Economic History $471987 \mathrm{pp}$. 897-927. J. Komlos, Anomalies in Economic History: Toward a Resolution of the 'Antebellum Puzzle', Journal of Economic History 561986 pp. 202-214. M.R. Haines, Health, Height, Nutrition, and Mortality: Evidence on the 'Antebellum Puzzle' from Union Army Recruits for New York States and the United States, in: J. Komlos/J. Baten, eds., The Biological Standard of Living in Comparative Perspective, Stuttgart 1998, pp. 155-180. L. Craig/M.R. Haines/T. Weiss, The Short and the Dead: Agricultural Surpluses, Mortality, and Stature in the Antebellum United States, paper presented at the Summer Institute of the Development of the American Economy Program, National Bureau of Economic Research, Cambridge, MA., 1997. A'Hearn, The Antebellum Puzzle Revisited: A New Look at the Physical Stature of Union Army Recruits during the Civil War, in: J. Komlos/J. Baten, eds., The Biological Standard of Living in Comparative Perspective, Stuttgart 1998, pp. 250-267.

5. Steckel, Stature and Living Standards in the United States, Figure 6.2.

6. See, for example, J. Riley, Sickness, Recovery and Death: A History and Forecast of Ill Health, Iowa City, IA 1989.

7. See, for example, R.W. Rogel/S.L. Engerman/J. Trussell, Exploring the Use of Data on Height: The Analysis of Long-Term Trends in Nutrition, Labor Welfare, and Labor Productivity, in: Social Science History 61982 , pp. 401-421. R.W. Fogel/S.L. Engerman/R. Floud/R.A. Margo/K. Sokoloff/R.H. Steckel/J. Trussell/G.C. Villaflor/K.W. Wachter, Secular Changes in American and British Stature and Nutrition, in: Journal of Interdisciplinary History, 14 1983, pp. 445-481. Fogel, Nutrition and the Decline in Mortality since 1700. R.W. Fogel, Nutrition and the Decline in Mortality since 1700: Some Additional Preliminary Findings, in: National Bureau of Economic Research. Working Paper No. 1802, 1986. R.W. Fogel, New Sources and New Techniques for the Study of Secular Trends in Nutritional Status, Health, Mortality, and the Process of Aging, in: Historical Methods, 26 1993, pp. 5-43. Komlos, The Height and Weight of West Point 
Cadets. Komlos, Stature, Living Standards, and Economic Development. Komlos, The Biological Standard of Living in Europe and America, 1700-1900. Komlos, The Biological Standard of Living on Three Continents. Komlos, Anomalies in Economic History. Komlos/Baten, The Biological Standard of Living in Comparative Perspective. R.H. Steckel, Slave Height Profiles from Coastwise Manifests, in: Explorations in Economic History, 1979 16. pp. 363-380. R.A. Margo/R.H. Steckel, The Heights of American Slaves: New Evidence on Slave Nutrition and Health, in: Social Science History, 1982 6. pp. $516-$ 538. R.A. Margo/R.H. Steckel, Heights of Native-Born Whites During the Antebellum Period, in: Journal of Economic History, 1983 43. pp. 167-174. K.L. Sokoloff/G.C. Villaflor, The Early Achievement of Modern Stature in America, in: Social Science History, 1982 6. pp. 453-481. R. Floud/K.W. Wachter, Poverty and Physical Stature: Evidence on the Standard of Living of London Boys 1770-1870, in: Social Science History, 1982 6. pp. 422-452. R. Floud/K.W. Wachter/A. Gregory, Height, Health, and History: Nutritional Status in the United Kingdom, 1750-1980, Cambridge, Eng. 1990.

8. See Fogel, Nutrition and the Decline in Mortality since 1700, Figure 9.1 and Table 9A.1. Steckel/Costa, Long-Term Trends in Health, Welfare, and Economic Growth in the United States.

9. Steckel, Height and Per Capita Income. Fogel, Nutrition and the Decline in Mortality since 1700. Fogel, New Sources and New Techniques for the Study of Secular Trends in Nutritional Status, Health, Mortality, and the Process of Aging. Haines, Health, Height, Nutrition, and Mortality: Evidence on the 'Antebellum Puzzle' from Union Army Recruits for New York States and the United States.

10. Sokoloff/Villaflor, The Early Achievement of Modern Stature in America.

11. Margo/Steckel, Heights of Native-Born Whites during the Antebellum Period. Haines, Health, Height, Nutrition, and Mortality: Evidence on the 'Antebellum Puzzle' from Union Army Recruits for New York States and the United States.

12. L.G. Sandberg/R.H. Steckel, Soldier, Soldier, What Made You Grow So Tall? in: Economy and History, 23 1980, pp. 91-105. L.G. Sandberg/R.H. Steckel, Heights and Economic History: the Swedish Case, in: Annals of Human Biology, 14 1987, pp. $101-110$. L.G. Sandberg/R.H. Steckel, Was Industrialization Hazardous to your Health? Not in Sweden! in: R.H Steckel/R. Floud, eds., Health and Welfare during Industrialization, Chicago 1997, pp. 127-160.

13. J. Komlos, Stature and Nutrition in the Habsburg Monarchy: the Standard of Living and Economic Development in the Eighteenth Century, in: American Historical Review, 90 1985, pp. 1149-1161.

14. J. Komlos, Anomalies in Economic History.

15. D. Weir, Economic Welfare and Physical Well-Being in France, 1750-1990, in: R.H Steckel/R. Floud, eds., Health and Welfare during Industrialization, Chicago 1997, pp. $161-200$.

16. S. Twarog, Heights and Living Standards in Germany, 1850-1939: The Case of Wuerttemberg, in: R.H Steckel/R. Floud, eds., Health and Welfare during Industrialization, Chicago 1997, pp. 285-331. 
17. J.W. Drukker/V. Tassenaar, Paradoxes of Modernization and Material Well-Being in the Netherlands in the Nineteenth Century, in: R.H Steckel/R. Floud, eds., Health and Welfare during Industrialization, Chicago 1997, pp. 331-378.

18. Floud/Wachter/Gregory, Height, Health, and History: Nutritional Status in the United Kingdom, 1750-1980.

19. See papers in Steckel/Floud, eds., Health and Welfare during Industrilization; and Komlos/Baten, eds., The Biological Standard of Living in Comparative Perspective.

20. C.B. Davenport/A.G. Love, Statistics: Army Anthropology, Vol. 15, Part 1, Medical Department, U.S. Army, The Medical Department of the United States Army in the World War, Washington, DC 1921. The original micro data of the muster records have not been made available for research.

21. Sokoloff/Villaflor, The Early Achievement of Modern Stature in America. Davenport/Love, Statistics: Army Anthropology, Table 5.

22. Calculated from Davenport/Love, Statistics: Army Anthropology, Table 2. Age was not recorded originally, though it was subsequently sought at mustering out.

23. G. Astor, The Right to Fight: A History of African Americans in the Military, Novato, CA 1998, ch. 8 .

24. Davenport/Love, Statistics: Army Anthropology, p. 117, Table 26. Very few Amerindians, Chinese, or Japanese served.

25. For example, the expectation of life at birth was 54.6 years for the white population versus 43.2 years for the black population, based on indirect estimates from the census of 1910. See M. Haines, Estimated Life Tables for the United States, 18501910, in: Historical Methods, 31 1998, pp. 149-169. The equality of heights of blacks and whites was likely partly due to the more predominantly rural residence of the black population (83\% in 1910 verus 51\% for whites). But there also may have been an element of selectivity - possibly only the most robust of young black men were taken for service.

26. Davenport/Love, Statistics: Army Anthropology, Tables 13, 17, 21, $32,33$.

27. R.A. Easterlin, State Income Estimates, in: E.S. Lee/A.R. Miller/C.P. Brainerd/R.A. Easterlin, Population Redistribution and Economic Growth in the United States, 18701950, I, Methodological Considerations and Reference Tables, Philadelphia 1957, pp. 703759.

28. S.H. Preston/M.R. Haines, Fatal Years: Child Mortality in Late Nineteenth Century America, Princeton, NJ 1991, ch. 2. M.R. Haines/S.H. Preston, The Use of the Census to Estimate Childhood Mortality: Comparisons from the 1900 and 1910 United States Census Public Use Samples, Historical Methods, 30 1997, pp. 77-96.

29. S. Ruggles/M. Sobek with C.A. Fitch/P.K. Hall/C. Ronnander, Integrated Public Use Microdata Series, Version 2.0, User's Guide, 1, Minneapolis, MN 1997.

30. M.R. Haines, The American Population, 1790-1920, in: S.L. Engerman/R.E. Gallman, The Cambridge Economic History of the United States, II, New York forthcoming. 
31. Costa/Steckel, Long-Term Trends in Health, Welfare, and Economic Growth in the United States, Table 2.1.

32. Oklahoma (1908), New Mexico (1912), and Arizona (1912) became states during the period considered here and are included in the analysis.

33. Davenport/Love, Statistics: Army Anthropology, pp. 80-103.

34. The BMI was chosen as the single anthropometric index in the mortality index regressions because it combines both height and weight.

35. H. Kaelble, Historical Research on Social Mobility, New York 1981.

36. Precise data on nativity were not furnished by Davenport and Love, but it appears that a very large proportion of the recruits were native-born. Of the 103,212 recruits remeasured at demobilization in 1919, 28,595 (27.7\%) were of foreign stock from eight major ethnic groups (English, Scottish, Irish, German, French, Polish, Italian, Jewish). This included both foreign-born recruits and native-born recruits of foreign or mixed parentage. Those from English Canada, Australia, and New Zealand were classed as English, and those from French Canada and francophone Switzerland were classed as French. German-speaking Swiss were classed as Germans. In 1910, these groups constituted about 71\% of all foreign-born whites. Foreign-born whites were 41\% of the foreign white stock (the foreign born plus those of foreign or mixed parentage). This translates to about 16,500 estimated foreign-born, or about 16\% of all recruits. This is a likely overestimate, since the original 28,595 included some who had only foreignborn grandparents and were not first or second generation immigrants. See Davenport/Love, Statistics: Army Anthropology, pp. 60-62, Table 24. U.S. Bureau of the Census, Thirteenth Census of the United States: 1910. Abstract of the Census, ch. 6 .

37. It is unlikely that this is due to the construction of the child mortality index itself. The index relies on information from the census records for individual adult women. There is no linking of data. The index has been tested against other mortality estimates based on published census and vital statistics information and found to perform quite well. See Haines/Preston, The Use of the Census to Estimate Childhood Mortality.

38. R.I. Rotberg and T.K. Rabb, eds., Hunger and History: The Impact of Changing Food Production and Consumption Patterns of Society, New York 1985, p. 308. See also M. Livi-Bacci, Population and Nutrition: An Essay on European Demographic History, New York 1991, pp. 36-39.

39. Calculated from U.S. Bureau of the Census, Twelfth Census of the United States: 1900, Vital Statistics, Part II, Statistics of Death, Washington, DC 1902, Table 8.

40. Blacks were, however, somewhat heavier on average by about five pounds.

41. Steckel, Stature and the Standard of Living, passim.

42. See Preston/Haines, ch. 1.

43. Easterlin, State Income Estimates. R.A. Easterlin, Interregional Differences in Per Capita Income, Population, and Total Income, 1840-1950, in: Trends in the American Economy in the Nineteenth Century, Princeton, NJ 1960, pp. 73-140. 
44. S.R. Johannson, Food for Thought: Rhetoric and Reality in Modern Mortality History, in: Historical Methods 27 1994, pp. 101-125. 
TABLE 1. HEIGHTS OF NATIVE-BORN WHITE MALES. UNITED STATES, 1755-1944.

$\begin{array}{llcc}\begin{array}{l}\text { DATES OF } \\ \text { MEASUREMENT }\end{array} & \text { AGE } & \begin{array}{c}\text { SAMPLE } \\ \text { SIZE }\end{array} & \begin{array}{l}\text { MEAN } \\ (\mathrm{cm})\end{array} \\ 1755-63(\mathrm{a}) & 24-35 & 767 & 172.0 \\ 1755-63(\mathrm{~b}) & 21-30 & 885 & 172.2 \\ 1775-83 & 24-35 & 968 & 172.9 \\ 1861-65 & 25-30 & 123,472 & 173.2 \\ 1917-18 & 21-30 & 868,445 & 171.4 \\ 1943-44 & 20-24 & 119,443 & 173.2\end{array}$

SOURCE: Reproduced from R.H. Steckel, "Stature and Living Standards", Table 6.7. 1755-1763(a) and 1775-1783: K.L. Sokoloff/G.C. Villaflor, The Early Achievement of Modern Stature in America, in: Social Science History, 1982 6, pp. 453-481. 17551763(b): A.T. Steegmann, Jr./P.A. Haseley, Stature Variation in the British American Colonies: French and Indian War Records, 1755-1763, in: American Journal of Physical Anthropology, 1988 75, pp. 413-421. 1861-1865: B.A. Gould, Investigations in the M11itary and Anthropological Statistics of American Soldiers, Cambridge, MA 1869. 1917-1918: C.B. Davenport/A.G. Love, Statistics: Army Anthropology, Vo1. 15, Part 1, Medical Department, U.S. Army, The Medical Department of the United States Army in the World War, Washington, DC 1921. 1943-1944: B.D. Karpinos, Height and Weight of Selective Service Registrants Processed for Military Service during World War II, in: Human Biology, 195830 , pp. 292-321. 
TABLE 2. RELATIONSHIP OF CHIL MORTALITY Ca 1904 \& 1895, AND THE PHYSICAL

CHARACTERISTICS OF WORLD WAR 1 RECRUITS, 1917/18. UNITED STATES. STATE LEVEL DATA.

\section{VARIABLE}

MEAN

\section{DEPENDENT VARIABLE}

STAND. ERROR

CORRELA- COEFF. SIGNI.

CHILD MORTALITY INDEX: 1900

\begin{tabular}{lr} 
Constant & \multicolumn{1}{|c}{} \\
Proportion Urban & 0.335 \\
Proportion Black & 0.116 \\
Proportion Foreign bom & 0.138 \\
MD's per 10,000 pop & 168.406 \\
Propor Adults Illterate & 0.124 \\
Persons per Dwelling & 5.055 \\
Persons per Family & 4.649 \\
Mean height (in) & 67.677 \\
Meen weight (lbs) & 142.003 \\
Body Mass Index & 21.798 \\
Eamings per worker, 1900 & 285.735 \\
Income per capita, 1900 & 123.796 \\
Region & \\
Northeast & 0.184 \\
North Central & 0.245 \\
South Attantic & 0.184 \\
South Central & 0.163 \\
West & 0.224
\end{tabular}

$N$

Adjusted R-squared F-ratio

Adjusted R-squared: Regions only

DEPENDENT VARIABLE:

Constant

Proportion Urban

Proportion Black

Proportion Foreign bom

MD's per 10,000 pop

Propor Adults illiterate

Persons per Dwelling

Persons per Family

Mortality index. 1910

Mortality Index 1900

Earnings per worker

Income per cepita

Region

Northeast

North Central

South Attantic

South Central

West

0.335
0.116
0.138
168.406
0.124
5.055
4.649

1.029
285.735
123.796

0.184
0.245
0.184
0.163
0.224

$N$

Adjusted R-squared

$$
\text { F-ratio }
$$

Adjusted R-squared: Regions only

0.227
0.175
0.101
51.292
0.111
0.555
0.313
0.511
2540
0.321
100.414
52.580

0.148
0.337
-0.162
0.083
0.502
0.002
-0.305
-0.250
-0.555
-0.416
-0.158
-0.070

0.196
-0.434
0.114
0.162
0.016

$\begin{array}{rr}2.126 & - \\ 0.267 & - \\ 0.041 & - \\ 0.779 & - \\ 0.000 & = \\ 1.418 & = \\ -0.426 & - \\ 0.007 & - \\ & \\ -0.000 & - \\ & \\ 0.027 & - \\ -0.064 & - \\ 0.152 & - \\ 0.194 & - \\ \text { N1 } & \end{array}$

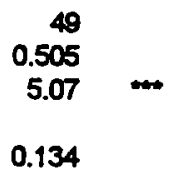

HEIGHT, 1917/18

(1900 State Data)

0.227
0.175
0.101
51.292
0.111
0.555
0.313
0.253
100.414
52.580

-0.723
0.226
-0.415
-0.052
0.220
-0.488
0.293

-0.250
0.038
-0.152
-0.796
0.143
-0.017
0.397
0.255

MEAN

STAND. ERROR

CORRELA- COEFF. SIGNI. TION

CHILD MORTALTY INDEX: 1910

0.389

0.110

0.139

0.083

4.980

4.512

67.677

142003

21.798

285.735

123.796

0.184

0.245

0.184

0.163

0.224

0.225
0.164
0.100
0.073
0.704
0.290
0.511
2540
0.321
100.414
52.580

-0.048
0.332
-0.207
0.646
0.121
0.038
-0.220
-0.580
-0.478
-0.190
-0.167
0.066
-0.476
0.237
0.157
0.069

\begin{tabular}{|c|c|}
\hline $\begin{array}{r}15.406 \\
0.063 \\
-0.967 \\
-0.280\end{array}$ & - \\
\hline 3.104 & $\infty$ \\
\hline $\begin{array}{l}-0.062 \\
-0.209\end{array}$ & $\overline{-}$ \\
\hline-0.000 & - \\
\hline $\begin{array}{l}-0.231 \\
-0.175 \\
-0.010 \\
-0.030 \\
\text { NI }\end{array}$ & $\begin{array}{l}- \\
- \\
-\end{array}$ \\
\hline
\end{tabular}

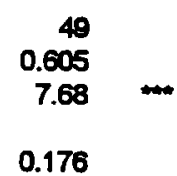

HEIGHT, 1917/18

(1910 State Data)

68.136

$-1.151$

0.258
0.002

0.389

0.110

0.139

0.083

4.980

4.512

0.947

$-0.274$

$0.000-$

285.735 123.796

0.184

$-0.749$

$-0.152-$

$-0.156-$

0.115

N!

0.245

0.184

0.163

0.224

0.225
0.164
0.100
0.073
0.704
0.290
0.223

0.414
52.580

49
0.806
23.17
0.690

$\begin{array}{rrr} & 68.066 & \cdots \\ -0.698 & -0.687 & \ldots \\ 0.234 & & \\ -0.521 & -1.121 & - \\ 0.165 & -0.176 & - \\ -0.590 & & \\ 0.142 & 0.194 & - \\ -0.220 & -0.557 & - \\ 0.038 & 0.000 & - \\ -0.152 & & \\ -0.796 & -0.864 & \cdots \\ 0.143 & -0.288 & - \\ -0.017 & -0.443 & - \\ 0.397 & -0.110 & - \\ 0.255 & N 1 & \end{array}$

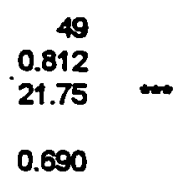


TABLE 2 (cont.)

DEPENDENT VARIABLE:

\section{Constart}

Proportion Urban

Proportion Black

Proportion Foreign borm

MD's per 10,000 pop

Propor Adults illiterate

Persons per Dwelling

Persons per Family

Mortallty index 1910

Mortality Index: 1900

Earnings per worker

Income per capita

Region

Northeast

North Central

South Attantic

South Centres

Weet

$$
N
$$

Adjusted R-squared Fratio

Adjusted R-squared: Regions only

SOURCE: See text.

- a not significant at least at a $10 \%$ level.

-m a significant at a 1\% level.

- = significant at a 5\% level.

- a significant at a 10\% level.

0.335
0.116
0.138
168.406
0.124
5.055
4.649

1.029
285.735
123.796
0.184
0.245
0.184
0.163
0.224

BODY MASS INDEX, 1917/18

(1900 State Data)

$\begin{array}{rr}0.227 & 0.237 \\ 0.175 & -0.595 \\ 0.101 & 0.801 \\ 51.292 & -0.012 \\ 0.111 & -0.632 \\ 0.555 & -0.032 \\ 0.313 & -0.309 \\ & \\ 0.253 & -0.416 \\ 100.414 & 0.604 \\ 52.580 & 0.654 \\ & 0.214 \\ & 0.386 \\ & -0.330 \\ & -0.551 \\ & 0.233\end{array}$

$21.559-$

$-0.162-$

$1.971 \quad \ldots$

0.000

$-0.276$

$0.001-$

0.142

$0.158=$

$0.164=$

$-0.014-$

NI

49

0.719

14.66

0.484
BODY MASS INDEX, 1917/18

(1910 State Data)

$\begin{array}{rrrrrr}0.389 & 0.225 & 0.275 & \begin{array}{l}21.682 \\ 0.376\end{array} & - \\ 0.110 & 0.164 & -0.595 & & \\ 0.139 & 0.100 & 0.757 & 2383 & \\ & & & & \\ 0.083 & 0.073 & -0.652 & -0.328 & - \\ 4.980 & 0.704 & 0.045 & & \\ 4.512 & 0.290 & -0.272 & 0.025 & - \\ 0.947 & 0.223 & -0.478 & -0.324 & - \\ & & & & \\ 285.735 & 100.414 & 0.604 & 0.000 & - \\ 123.796 & 52580 & 0.654 & & \\ & & & & \\ 0.184 & & 0.214 & 0.039 & - \\ 0.245 & & 0.359 & 0.114 & - \\ 0.184 & & -0.330 & 0.139 & - \\ 0.163 & & -0.559 & -0.057 & - \\ 0.224 & & 0.233 & N 1 & \end{array}$

49
0.710
1273
0.484


TABLE 3. RELATIONSHIP OF CHILD MORTALITY Ca $1904 \& 1895$, AND THE PHYSICAL

CHARACTERISTICS OF WORLD WAR 1 RECRUITS, 1917/18. UNITED STATES. COUNTY GROUPS.

VARIABLE . MEAN

DEPENDENT VARIABLE

Constant

Proportion Urban

Proportion Black

Propor. Foreign Bom White

Propor Adults Illiterate

Persons per Dwelling.

Persons per Family

Mean height (in)

Mean weight (lbs)

Body Mass Index

Region

New England

Middle Attantic

East North Central

West North Central

South Attantic

East South Central

West South Central

Mountain

Pacific

$$
\begin{gathered}
\mathbf{N} \\
\text { Adjusted } \mathbf{R} \text {-squared } \\
\text { F-ratio }
\end{gathered}
$$

Adjusted R-Squared: Regions only

DEPENDENT VARIABLE:

Constant

Proportion Urban

Proportion Black

Proportion Foreign bom

Propor Adults Ilitierate

Persons per Dwelling

Persons per Family

Mortality Index 1910

Mortality Index 1900

Region

Now England

Middle Allantic

East North Central

West North Central

South Atlantic

East South Central

West South Central

Mountain

Pacific

0.387
0.117
0.144
0.090
5.038
4.544
67.664
141.942
21.798

0.083
0.115
0.154
0.128
0.173
0.077
0.083
0.122
0.064

0.122

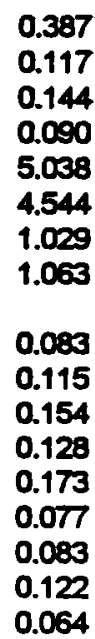

0.387

0.000

1029

0.154

0.077

0.122

0.064 ERROR

CORRELA- COEFF. SIGNI. TION

CORRELA- COEFF. SIGNI.

\begin{tabular}{|c|c|c|c|c|c|c|}
\hline \multirow{10}{*}{$\begin{array}{l}0.294 \\
0.185 \\
0.108 \\
0.087 \\
1.153 \\
0.354 \\
0.537 \\
2.506 \\
0.355\end{array}$} & & 13.487 & $\overline{-}$ & & 13.281 & $\infty$ \\
\hline & 0.090 & 0.574 & - & 0.040 & 0.226 & 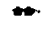 \\
\hline & 0.151 & -0.513 & - & 0.408 & -0.040 & - \\
\hline & -0.016 & -0.9003 & - & -0.104 & -0.064 & - \\
\hline & 0.396 & 4.030 & 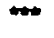 & 0.592 & 2183 & هم \\
\hline & 0.055 & & & 0.059 & & \\
\hline & -0.053 & -0.133 & - & 0.043 & -0.115 & - \\
\hline & -0.128 & -0.182 & - & -0.166 & -0.178 & $\ldots$ \\
\hline & -0.255 & & & -0.412 & & \\
\hline & -0.152 & & & -0.287 & & \\
\hline & 0.044 & NI & & 0.068 & NI & \\
\hline & -0.028 & -0.079 & - & -0.045 & -0.084 & - \\
\hline & 0.009 & 0.180 & - & -0.158 & 0.017 & - \\
\hline & -0.066 & 0.274 & - & -0.222 & 0.093 & - \\
\hline & -0.036 & -0.080 & - & 0.156 & 0.094 & - \\
\hline & 0.037 & -0.058 & - & 0.120 & 0.009 & - \\
\hline & 0.115 & 0.189 & - & 0.217 & 0.262 & $\infty$ \\
\hline & 0.061 & 0.166 & - & 0.091 & 0.153 & - \\
\hline & -0.127 & 0.011 & - & -0.212 & -0.049 & - \\
\hline & & 154 & & & 155 & \\
\hline & & 0.281 & & & 0.510 & \\
\hline & & 5.26 & $\cdots$ & & 1245 & هו \\
\hline & & 0.039 & & & 0.147 & \\
\hline
\end{tabular}
TION

CHILD MORTALITY INDEX: 1900 CHILD MORTALITY INDEX: 1910

\begin{tabular}{|c|c|c|c|c|c|c|}
\hline \multirow[b]{2}{*}{$\begin{array}{l}0.294 \\
0.185 \\
0.108 \\
0.087 \\
1.153 \\
0.354 \\
0.274 \\
0.465\end{array}$} & \multicolumn{3}{|c|}{$\begin{array}{l}\text { HEJGHT, 1917/18 } \\
\text { (1910 County Data) }\end{array}$} & \multicolumn{3}{|c|}{$\begin{array}{c}\text { BODY MASS INDEX, 1917/ } \\
\text { (1910 County Data) }\end{array}$} \\
\hline & $\begin{array}{r}-0.678 \\
0.213 \\
-0.533 \\
0.213 \\
-0.403 \\
0.097 \\
-0.166 \\
-0.128\end{array}$ & $\begin{array}{r}0.029 \\
-0.287\end{array}$ & - & $\begin{array}{r}0.266 \\
-0.422 \\
0.693 \\
-0.390 \\
0.142 \\
-0.084 \\
-0.287 \\
-0.152\end{array}$ & $\begin{array}{r}2318 \\
0.185 \\
-0.016 \\
-0.094\end{array}$ & $\infty$ \\
\hline & $\begin{array}{l}-0.403 \\
-0.547 \\
-0.103 \\
0.271 \\
0.053 \\
0.255 \\
0.263 \\
0.140 \\
0.112\end{array}$ & $\begin{array}{l}\text { NI } \\
-0.200 \\
0.385 \\
0.746 \\
0.383 \\
0.722 \\
0.813 \\
0.657 \\
0.734\end{array}$ & هـ & $\begin{array}{r}0.086 \\
0.221 \\
0.180 \\
0.272 \\
-0.347 \\
-0.324 \\
-0.291 \\
-0.041 \\
0.241\end{array}$ & $\begin{array}{l}N I \\
0.114 \\
0.073 \\
0.092 \\
-0.108 \\
-0.204 \\
-0.234 \\
-0.165 \\
0.197\end{array}$ & $\begin{array}{l}\overline{-} \\
\overline{-} \\
\ddot{\bullet} \\
\ddot{*}\end{array}$ \\
\hline & & $\begin{array}{r}155 \\
0.793 \\
46.45\end{array}$ & هـ & & $\begin{array}{r}155 \\
0.655 \\
20.61\end{array}$ & $m$ \\
\hline & & 0.622 & & & 0.443 & \\
\hline
\end{tabular}

HEIGHT, 1917/18 BODY MASS INDEX, 1917/1

(1910 County Data) (1910 County Data)
Ni

$$
0.180
$$

$-0.080$

$-0.058$

0.011

0.039

\footnotetext{
SOURCE: See text.

N

Adjusted R-squared F-ratio

Adjusted R-Squared: Regions only

- = not significant at least at a $10 \%$ level.

$\infty+$ s significant at a $1 \%$ level.

- = significant at a $5 \%$ level.

- = significant at a 10\% level.
} 

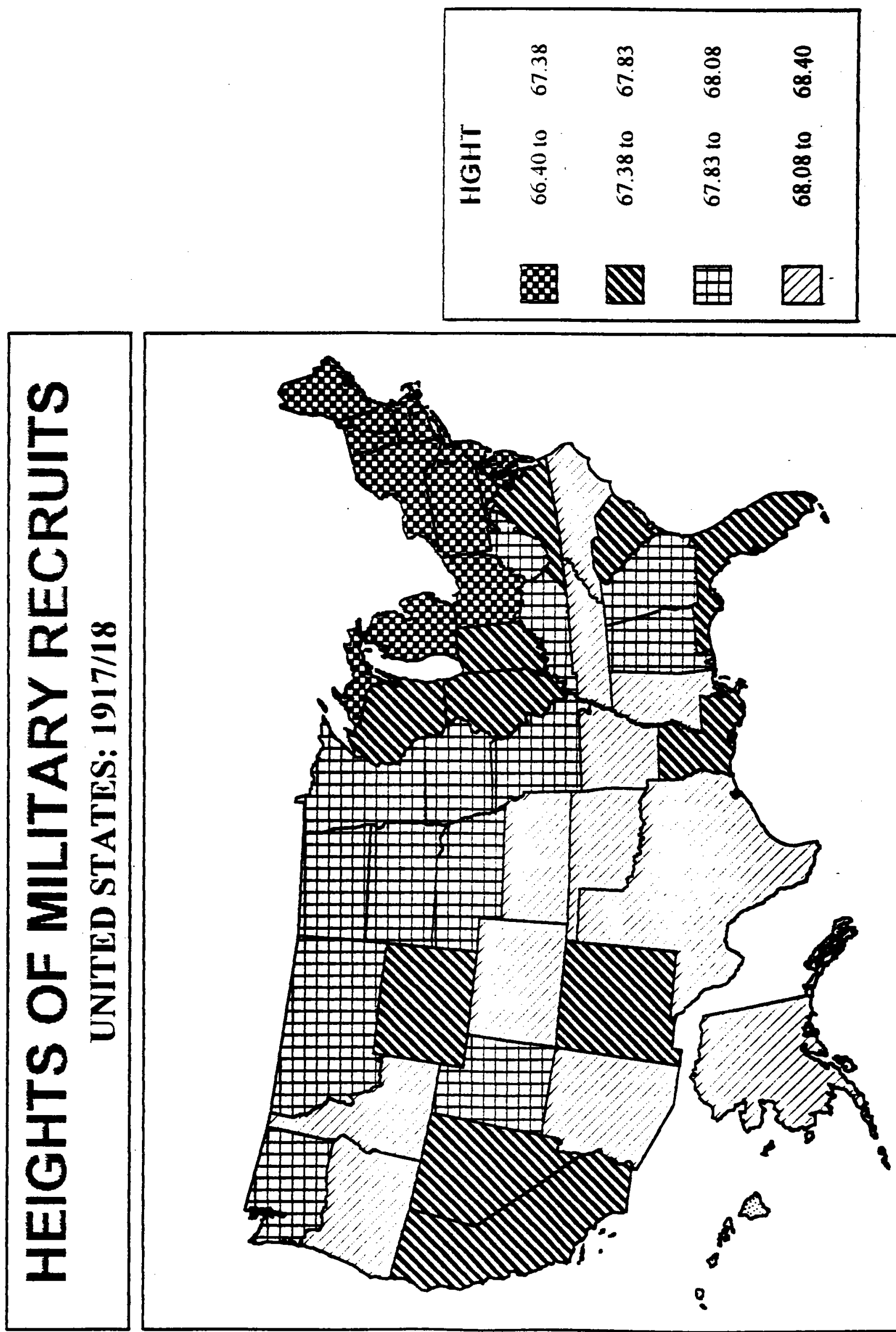

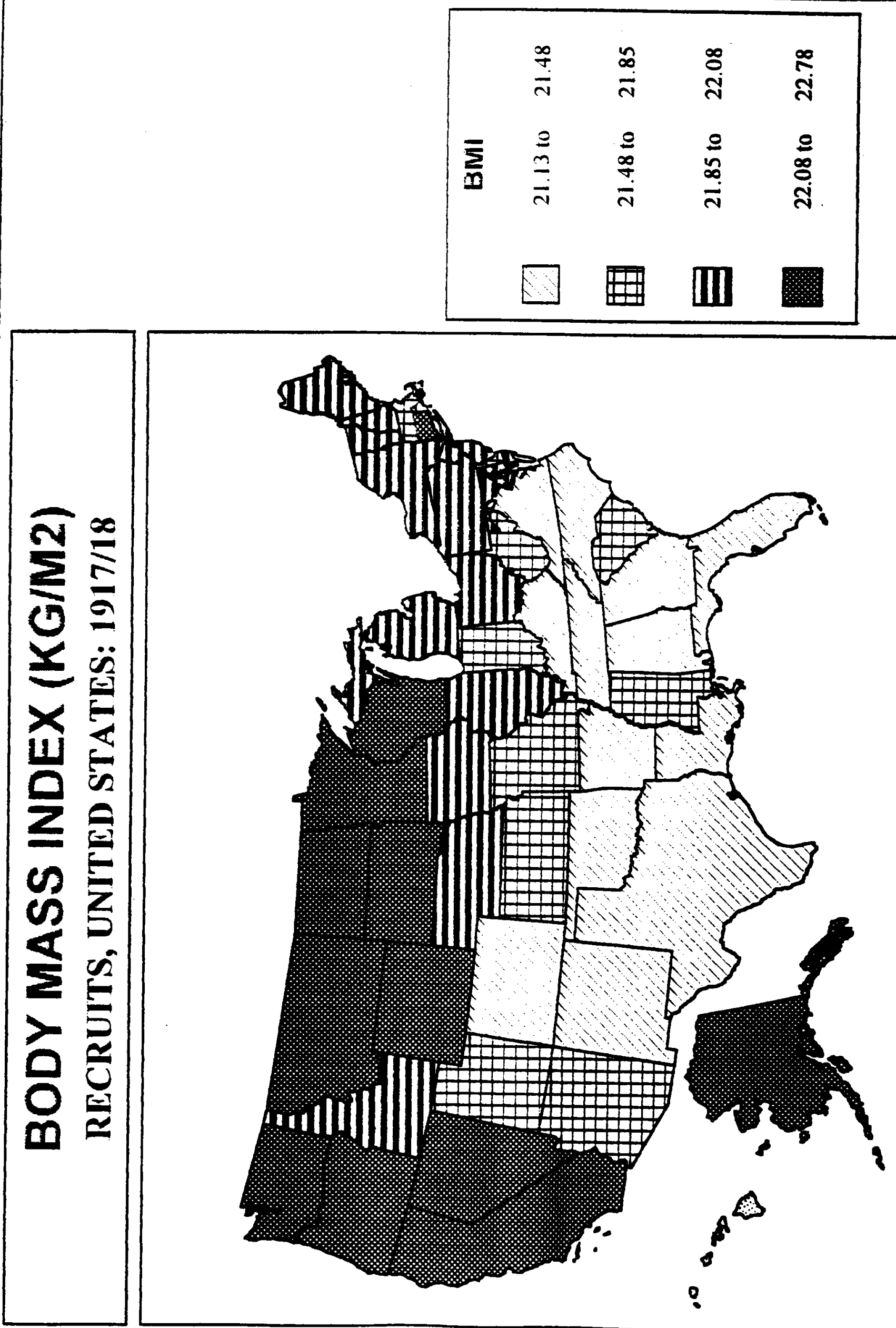

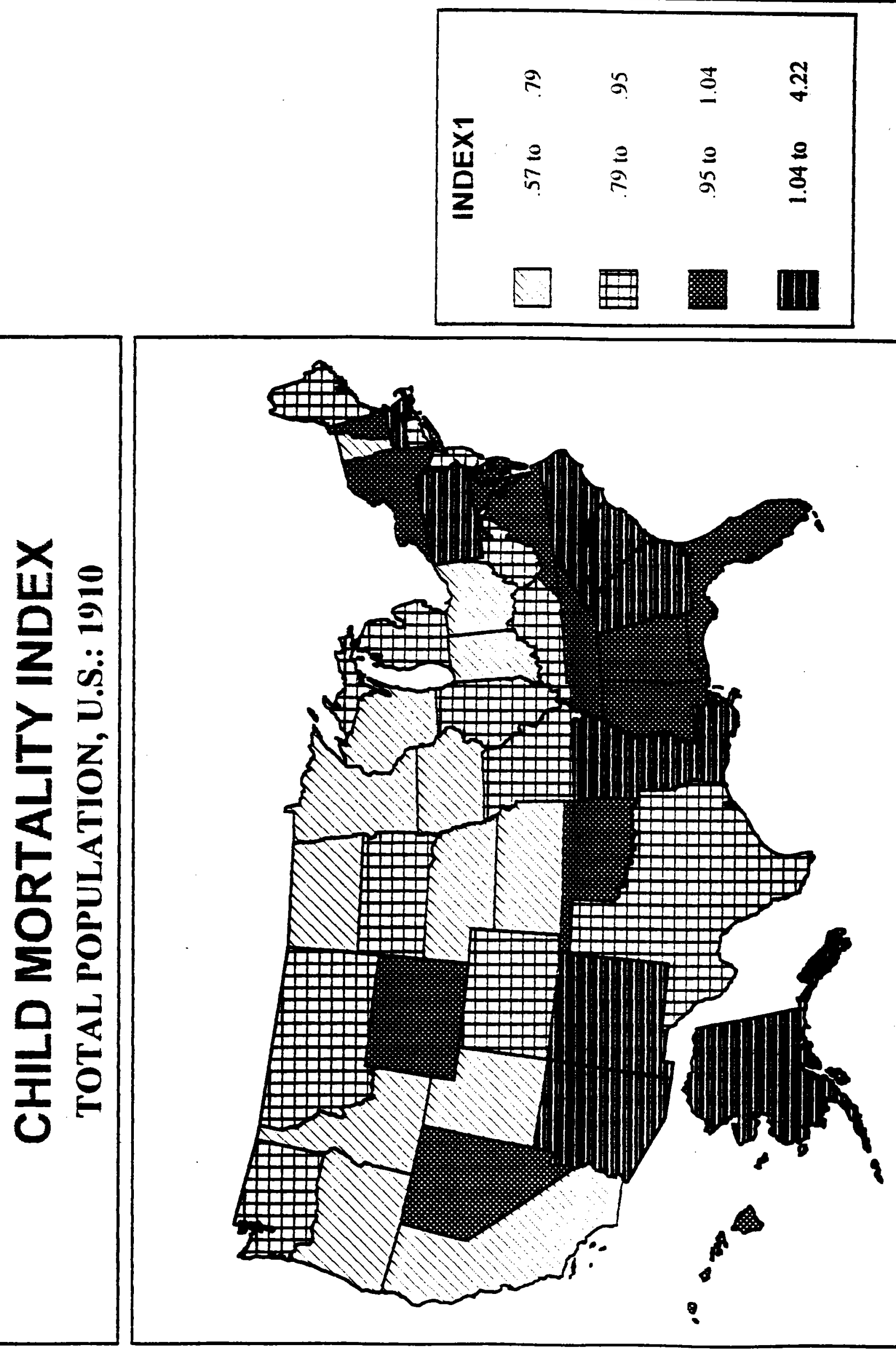